NOTICE: this is the author's version of a work that was accepted for publication in the journal Water Research. Changes resulting from the publishing process, such as peer review, editing, corrections, structural formatting, and other quality control mechanisms may not be reflected in this document. Changes may have been made to this work since it was submitted for publication. A definitive version was subsequently published in the journal Water Research, Vol.60 (2014). DOI: http://doi.org/10.1016/j.watres.2014.04.043 


\section{Which chemicals drive biological effects in wastewater and}

\section{2 recycled water?}

3 Janet Y. M. Tang, ${ }^{a}$ Francesco Busetti, ${ }^{b}$ Jeffrey W.A. Charrois, ${ }^{b}$ Beate I. Escher ${ }^{a * \#}$

4 The University of Queensland, National Research Centre for Environmental Toxicology

5 (Entox), 39 Kessels Rd, Coopers Plains, QLD 4108, Australia

$6 \quad{ }^{\mathrm{b}}$ Curtin University, Curtin Water Quality Research Centre (CWQRC), GPO Box U1987,

7 Perth, WA 6845, Australia

8

$9 *$ corresponding author e-mail address b.escher@uq.edu.au, telephone +61 732749009 ,

$10 \quad$ Fax +61732749003.

11 \#present address: Helmholtz Centre for Environmental Research GmbH - UFZ,

12 Department of Cell Toxicology, Permoserstraße 15, 04318 Leipzig, Germany

13 


\section{Abstract}

15 Removal of organic micropollutants from wastewater during secondary treatment

16 followed by reverse osmosis and UV disinfection was evaluated by a combination of four

17 in-vitro cell-based bioassays and chemical analysis of 299 organic compounds.

18 Concentrations detected in recycled water were below the Australian Guidelines for

19 Water Recycling. Thus the detected chemicals were considered not to pose any health

20 risk. The detected pesticides in the wastewater treatment plant effluent and partially

21 advanced treated water explained all observed effects on photosynthesis inhibition. In

22 contrast, mixture toxicity experiments with designed mixtures containing all detected

23 chemicals at their detected concentrations demonstrated that the known chemicals

24 explained less than $3 \%$ of the observed cytotoxicity and less than $1 \%$ of the oxidative

25 stress response. Pesticides followed by pharmaceuticals and personal care products

26 dominated the observed mixture effects. The detected chemicals were not related to the

27 observed genotoxicity. The large proportion of unknown toxicity calls for effect

28 monitoring complementary to chemical monitoring.

30 Keywords

31 Effect-based monitoring, bioanalytical equivalent concentrations, mixture toxicity,

32 reverse osmosis, recycled water 


\section{Introduction}

36 Indirect potable reuse (IPR) of wastewater has become a necessity in many water-scarce

37 regions of the world (National Research Council 1998, Rodriguez et al. 2009, Sedlak

38 2014). IPR schemes typically rely on advanced treatment of secondary wastewater

39 effluents from wastewater treatment plant (WWTP). Such advanced treatment usually

40 consists of a combination of membrane filtration (e.g. ultrafiltration and reverse osmosis)

41 and oxidation processes (e.g. advanced oxidation, UV disinfection) to remove pathogens

42 and chemicals, including inorganics and heavy metals, nutrients and organic

43 micropollutants (Binnie and Kimber 2009). Recycled water is then introduced into

44 aquifers or waters and can potentially be used as part of the drinking water supply. As

45 reviewed recently (Rodriguez et al. 2009, van der Bruggen 2010), a large number of IPR

46 schemes have been implemented in the US, as well as some in the UK, Namibia, and

47 Singapore. To date, no adverse health impacts have been reported related to recycled

48 water (Khan and Roser 2007).

49 In Australia, there are two major IPR projects. On the East Coast, the Western

50 Corridor Recycled Water Project is Australia's largest water recycling scheme and the

51 third-largest advanced water treatment project in the world. It was commissioned in 2008

52 but ultimately the scheme has not become operational up to 2014 because the 2003-2008

53 drought in Southeast Queensland ended with a period of heavy rainfalls and floods from

54 mid-2010 onwards. On the West Coast, a pilot IPR scheme has been successfully

55 implemented from 2010 to 2012 that treats secondary effluent from the Beenyup WWTP

56 with ultrafiltration (UF) followed by reverse osmosis (RO) and final UV disinfection. The 
57 recycled water is injected into the Leederville aquifer, which is a drinking water source

58 for the city of Perth (Water Corporation 2013). This scheme has been approved to go to

59 full scale, with stage one expected to be completed in 2016

60 (http://www.watercorporation.com.au). This managed aquifer recharge scheme is the

61 focus of this paper.

62 Most IPR schemes extensively investigated potential environmental and human

63 health impact of the replenishment of drinking water reservoirs with recycled water

64 before implementation. Typically a large number of organic micropollutants known to

65 occur in sewage or formed from natural precursors during treatment processes (e.g.,

66 disinfection by-products) are monitored through chemical analyses. These include

67 pharmaceuticals and personal care products, pesticides, household and industrial

68 chemicals. While micro- or ultra-filtration mainly remove bacteria, pathogens and high

69 molecular-weight natural organic matter, most organic micropollutants are removed

70 during RO treatment (Gupta and Ali 2013). However, low molecular weight and non-

71 ionic (neutral) organic molecules (e.g. NDMA, dioxane, halogenated solvents) were less

72 effectively rejected by RO membranes. As a result, these compounds are frequently

73 detected in recycled water at low concentrations (Snyder et al. 2007, Drewes et al. 2008).

74 Taking a precautionary approach, frequently detected organic micropollutants in

75 recycled water are tightly regulated in many countries. In the US, recycled water has to

76 comply with drinking water guidelines. The Australian Guidelines for Water Recycling

77 (AGWR) lists 348 organic chemicals with health-based guideline values (GVs)

78 (NRMMC \& EPHC \& NHMRC 2008). The GVs generally match the Australian 
79 Drinking Water Guidelines (ADWG) (NHMRC 2011) but almost twice as many

80 chemicals are regulated in recycled water. Fifteen regulated organic micropollutants were

81 occasionally detected in recycled water of the Western Corridor Recycled Water Project

82 (Hawker et al. 2011) but concentrations never exceeded GVs. In addition the potential

83 impact on the receiving dam was modeled, and concentrations of organic chemicals were

84 expected to decrease further due to dilution and natural attenuation, mainly by

85 biodegradation and sorption to sediments (Hawker et al. 2011).

86 In an initial investigation (2005 - 2008) of the IPR scheme in Perth, 396

87 parameters were monitored over three years (Van Buynder et al. 2009). While 23 organic

88 chemicals and 6 metals/inorganics were detected in more than $25 \%$ of all RO waters

89 investigated, all concentrations of chemicals in RO water were below GVs. The organics

90 detected in RO permeate were mainly disinfection by-products (e.g., NDMA), small

91 volatile organics (e.g., benzene, dioxane) and complexing agents (e.g., EDTA, NTA).

92 Detected concentrations were below GVs and were not considered to pose any

93 appreciable health risk, with one exception, the disinfection by-product NDMA (Linge et

94 al. 2012). However, there remain unknowns because the detected chemicals could only

95 explain a small fraction $(\sim 2-5 \%)$ of the dissolved organic carbon in the RO permeate

96 (Linge et al. 2012). While up to $95 \%$ of dissolved organic carbon in RO permeate could

97 not be accounted for, chemicals below detection limit may have contributed to the

98 residual DOC, along with low molecular-weight natural organic matter originally present

99 in drinking water and wastewater, unknown anthropogenic micropollutants, chemicals 
100 used during RO treatment or leached from RO membranes and soluble microbial by-

101 products (Linge et al. 2012).

102 To bridge this knowledge gap, target and non-target screening were conducted

103 recently in water post RO and post UV using an Orbitrap MS spectrometer (Busetti et al.

104 2013). Both target and non-target screening showed that (a) "suspect" or "unknown"

105 chemicals did not make up the majority of the DOC in RO treated water, and (b) a large

106 number anthropogenic chemicals targeted (i.e., pesticides, biocides, industrial chemicals,

107 pharmaceuticals) were not detected in recycled water, further reducing the risk associated

108 with human consumption of recycled water.

109 Furthermore, during Perth's Groundwater Replenishment Trial, which ended in

110 2012, 292 Recycled Water Quality Parameters were monitored over three years. The

111 results of this extensive monitoring program confirmed $100 \%$ compliance of all water

112 samples analysed with the required water quality guidelines (Water Corporation 2013).

113 In the present study, chemical analysis was complemented with bioanalytical

114 tools. Cell-based bioassays are widely used for water quality assessment and monitoring

115 (Escher and Leusch 2012) and have previously been applied to evaluate water quality

116 from samples taken in the investigated IPR scheme (Leusch et al. 2014a, Leusch et al.

117 2014b).

118 Cell-based bioassays can provide a comprehensive profile of the biological

119 activity of mixtures of organic chemicals and can also give information on the type of

120 effect by choosing cells and assessment endpoints that are associated with defined modes

121 of action (Escher and Leusch 2012). So far, investigated modes of action have 
122 predominantly focused on estrogenic and other endocrine effects as well as genotoxicity

123 (Escher and Leusch 2012). We previously applied 100 distinctly different bioassays to

124 recycled water and demonstrated that a small number of indicator bioassays can be

125 applied for monitoring of the treatment efficacy as well as for benchmarking the water

126 quality of recycled water against other types of water (Escher et al. 2014a). According to

127 these recommendations four bioassays were used in this study: non-specific toxicity

128 (cytotoxicity) was evaluated with the bioluminescence inhibition test with Vibrio fischeri

129 (Microtox) (Tang et al. 2013). Photosynthesis inhibition using the combined algae test

130 (Escher et al. 2008) was a representative specific mode of action. We also determined

131 estrogenicity with the ER-CALUX (Rogers and Denison 2000) and the activation of the

132 aryl hydrocarbon receptor with the AhR-CALUX (Nagy et al. 2002) assay but these two

133 bioassays did not show any responses and were therefore not suitable for the mixture

134 modeling.

135 Reactive toxicity was assessed with the umuC assay for genotoxicity (Macova et

136 al. 2011) and the AREc32 for oxidative stress response (Escher et al. 2012). In addition,

137 we quantified 299 organic micropollutants during the same sampling campaign.

138 The aim of the study was to assess which of the detected chemicals drive the

139 biological effect and which fraction of effect remains unexplained by detected chemicals.

140 Therefore we mixed all chemicals that were (a) present at concentrations above the limit

141 of detection (LOD) and (b) included in the AGWR. These chemicals were mixed in the

142 concentration ratios that were detected by analytical chemistry in the various samples.

143 These mixtures were termed "iceberg mixtures" as they constituted the visible "tip of the 
144 iceberg" and allowed us to estimate the contribution of unknown chemicals and

145 chemicals below detection limits to the overall mixture effect. We have previously

146 performed such experiments with wastewater and recycled water and were able to show

147 that known chemicals can explain the majority of specific receptor-mediated effects

148 (Tang and Escher 2014) but for more general endpoints such as cytotoxicity (Tang et al.

149 2013) and oxidative stress response (Escher et al. 2013) less than $1 \%$ of effect could be

150 explained by known chemicals.

151 In addition to the four biological endpoints evaluated here, estrogenicity is a

152 highly relevant biological endpoint in wastewater and associated water types. However,

153 previous work has demonstrated that no estrogenic activity could be detected in recycled

154 water (Leusch et al. 2014a), and that the estrogenicity in typical source water can be fully

155 explained by known chemicals (Rutishauser et al. 2004). Therefore, and because no

156 estrogenic responses were detected in the investigated waters, this endpoint was omitted

157 in the present study.

158 The present study does not only apply this iceberg concept to a different and more

159 diverse set of samples in a recycling plant but goes a step further in that the iceberg

160 mixtures were subdivided into six chemical groups (pharmaceuticals (including personal

161 care products), endocrine disruptors compounds (EDCs), antibiotics, X-ray contrast

162 media (XRCs), pesticides (including transformation products) and others). By comparing

163 the effects of the individual groups and the effects of the combined iceberg mixtures, it

164 could be determined, which chemical group dominates or significantly contributes to the

165 biological effects at any stage of the treatment process. 


\section{$167 \quad 2.1$ Chemicals}

168 The 65 chemicals used in the mixture experiments are listed in the Electronic

169 Supplementary Material (ESM), Table S1. All chemicals were of analytical grade and

170 purchased from Sigma-Aldrich or Novachem, Australia.

\section{$171 \quad 2.2$ Sampling site}

172 Grab samples were collected from a Wastewater Treatment Plant (WWTP) and an

173 Advanced Water Recycling Plant (AWRP) located in Perth, Western Australia in July

1742012 (Figure 1). The WWTP treats predominately urban residential sewage

175 (Water Corporation 2013). Briefly, the raw wastewater is treated with grit removal and

176 goes through sedimentation tanks (WWTP influent). This water then undergoes aeration,

177 activated sludge treatment and clarification as a secondary treatment. The majority of the

178 resulting secondary treated effluent (WWTP effluent) is discharged into the ocean and a

179 small portion ( $7 \mathrm{ML} /$ day) is fed into the AWRP. The treatment train of the AWRP

180 consists of chloramination for disinfection during treatment process, ultrafiltration,

181 reverse osmosis and ultraviolet light (UV) disinfection. Samples were collected in the

182 following points: after the sedimentation tanks in the WWTP (WWTP influent); after

183 secondary treatment (WWTP effluent); after ultrafiltration (post UF); before reverse

184 osmosis in the holding tank (mixing tank); after reverse osmosis (post RO); after UV

185 disinfection (post UV). The reverse osmosis reject (RO reject) was also collected. The

186 recycled water was injected into the groundwater system at a maximum of 4.5 ML/day.

187 Routine water quality data was assessed by the plant operators at the time of sampling 
188 and is given in the ESM, Table S2. In addition, a laboratory blank (LB) and a field blank

189 (FB) were made up of ultrapure water.

$191 \quad 2.3$ Sampling and sample preparation

192 The water samples were collected in amber glass bottles and preserved with $0.1 \%$ sodium

193 thiosulphate and concentrated hydrochloric acid to $\mathrm{pH}$ 2.5. The samples were split into

194 two portions, for chemical analyses and bioassays. For bioassays, all samples were

195 filtered with $0.45 \mu \mathrm{m}$ microfiber glass Duo-Fine filter cartridges (PALL Life Sciences,

196 NY, USA) before solid-phase extraction (SPE) in $20 \mathrm{~mL}$ custom-made cartridges from

197 Supelco (Sigma-Aldrich, Sydney, Australia). The extraction material was comprised of 2

$198 \mathrm{~g}$ SupelClean coconut charcoal and $1 \mathrm{~g}$ SupelSelect HLB with frits in between. The

199 cartridges were conditioned with $20 \mathrm{~mL}$ acetone:hexane mixture (1:1, v:v), followed by

$20020 \mathrm{~mL}$ methanol and $20 \mathrm{~mL}$ ultrapure water at $\mathrm{pH} 3$ at a flow rate of $5 \mathrm{~mL} / \mathrm{min}$. Samples

201 were then loaded onto the custom-made cartridges using three 8-channel offline

202 peristaltic pumps (Gilson, Middleton, USA) at a flow rate of $3 \mathrm{~mL} / \mathrm{min}$. The cartridges

203 were dried under vacuum and wrapped in parafilm and aluminium foil and stored at -20

$204{ }^{\circ} \mathrm{C}$ before shipping to the Entox laboratory for elution. The cartridges were eluted with 20

$205 \mathrm{~mL}$ methanol and $20 \mathrm{~mL}$ acetone:hexane mixture (1:1, v:v) under gravity. The extracts

206 were evaporated under gentle nitrogen flow and solvent-exchanged into $1 \mathrm{~mL}$ of

207 methanol.

208 The SPE extracts were comprised of a mixture of known and unknown chemicals at

209 unknown concentrations. The dose-metric is the relative enrichment factor (REF), which 
210 is a measure of how much a sample is enriched $(\mathrm{REF}>1)$ or diluted $(\mathrm{REF}<1)$ in the

211 bioassay as compared to the original sample (equation 1).

$212 \mathrm{REF}=\frac{\text { water volume equivalent in bioassay }}{\text { total volume of medium in bioassay }}$

\section{$214 \quad 2.4$ Chemical analysis}

215 Water samples were analyzed using GC/MS-MS and LC/MS-MS at Queensland Health

216 Forensic Scientific Services and at the Curtin Water Quality Research Centre (CWQRC).

217 A total of 299 chemicals were analyzed between the two laboratories. More details on the

218 sample preparation for chemical analysis and analytical methods are given in the ESM

219 Data, Section S1.

\section{$221 \quad 2.5$ Designed iceberg mixtures}

222 Detected chemicals were mixed in the ratios of concentrations found (ESM, Table S3).

223 The detected chemicals were clustered in six groups: endocrine disrupting compounds

224 (EDCs), antibiotics, X-ray contrast media (XRCs), pesticides (including transformation

225 products), pharmaceuticals (excluding antibiotics but including personal care products

226 such as triclosan and consumer products such as coffeine) and "others" (ESM, Table S3).

227 In addition, the individual chemical group mixtures were mixed according to the

228 contributing fraction into one mixture comprising all detected chemicals termed as

229 "iceberg mixture".

230 


\subsection{Bioanalytical assessment}

232 All bioassays were previously applied and characteristics of the bioassays and literature

233 references for the methods are given in Table 1. For each sample, the bioanalytical

234 equivalent concentration BEQ was calculated from the effect concentration EC of the

235 reference compound divided by the EC of the water sample.

$236 \mathrm{BEQ}_{\text {water }}=\frac{\mathrm{EC}(\text { reference compound })}{\mathrm{EC}(\text { water sample })}$

237 In case of the water samples, the EC is in units of REF and the BEQ is termed $\mathrm{BEQ}_{\text {water. }}$

238 Analogously the BEQ of designed iceberg mixtures BEQiceberg and the individual

239 chemical groups $\mathrm{BEQ}_{\text {group } \mathrm{i}}$ can be derived with equation 3 by using the $\mathrm{EC}$ values

240 experimentally obtained from the designed chemical mixtures (in units of mol/L) and

241 converted to the EC in units of REF, EC(iceberg,REF), using the known chemical

242 concentrations $\mathrm{C}$ in the mixture equivalent to the measured concentrations in the sample

243 (sum of concentrations in units of $\mathrm{mol} / \mathrm{L}$ ).

$244 \mathrm{BEQ}_{\text {iceberg }}=\frac{\mathrm{EC}(\text { reference compound })}{\frac{\mathrm{EC}(\text { iceberg, } \mathrm{M})}{\mathrm{C}(\text { iceberg })}}=\frac{\mathrm{EC}(\text { reference compound })}{\mathrm{EC}(\text { iceberg, } \mathrm{REF})}$

245 The reference compounds and the associated BEQ for each bioassay are defined in Table

246 1. The limits of detection were derived by translating the effect of three times the

247 standard deviation of the controls into the corresponding BEQ values (Table 1). 


\section{Results and Discussion}

\subsection{Chemical analysis}

252 A total of 299 chemicals were analyzed in the water samples, of which 172 were included

253 in the AGWR (ESM, Figure S1). In the paper, we focus the discussion on the regulated

254 chemicals (ESM, Table S3), while results on additional non-regulated chemicals are

255 compiled in the ESM, Table S4. The highest number of chemicals were detected in

256 WWTP influent, WWTP effluent, post UF and mixing tank (50, 50, 49, 50, respectively,

257 ESM, Figure S1). The concentrations of chemicals in the WWTP influent were typically

258 higher than in WWTP effluent, although due to the higher LOD in the WWTP influent

259 sample, some chemicals were not detected in the WWTP influent but found in the

260 WWTP effluent. UF did not reduce concentrations of chemicals. Instead, RO was found

261 to be a very effective removal process and only five chemicals were detected in the post

262 RO sample however, no chemicals were detected post-UV disinfection. In the post RO

263 sample, low levels of the anticorrosive chemical tolytriazole, the plasticizer bisphenol A,

264 the pharmaceutical triclosan and the pesticides MCPA and the pesticide degradation

265 product 3,4-dichloroaniline were detected. Tolytriazole (Busetti et al. 2013, Loi et al.

266 2013) and bisphenol A (Water Corporation 2013) were detected in previous monitoring

267 programs but triclosan and the pesticides MCPA and 3,4-dichloraniline were detected in

268 post RO water for the first time in this AWRP. No chemicals were detected in the post

269 UV water sample.

270 The chemicals' concentrations in post RO and post UV samples were below the

271 Australian GVs for recycled water (NRMMC \& EPHC \& NHMRC 2008). For 
272 comparison, the GVs are indicated in Figure 2 by black bars. If at all, the concentrations

273 exceeded the GVs for recycled water only in WWTP influent or RO reject. Exceptions

274 were the pesticide MCPA, which exceeded the GV prior to the RO treatment but was two

275 orders of magnitude below the GV in RO water, and resulted below detection in the post

276 UV sample. Diatrizoic acid was also above GV up to the mixing tank but was below

277 detection after RO.

278 The majority of detected chemicals fell into the group of pharmaceuticals with 34

279 out of 44 analyzed pharmaceuticals being detected in at least one sample (Figure 2). Five

280 pharmaceuticals (citalopram, desmethylcitalopram, cyclophosphamide, fluoxetine and

281 propranolol) were not detected in WWTP influent due to increased LODs in the complex

282 sewage matrix but were present in the WWTP effluent. In general, concentrations were

283 significantly reduced during secondary treatment (Figure 2) and nine pharmaceuticals

284 (acetylsalicylic acid, acetaminophen, atorvastatin, cephalexin, ibuprofen, naproxen,

285 ranitidine, salicylic acid and theophylline) were below detection limit after secondary

286 treatment. Concentrations of carbamazepine, diclofenac, fluoxetine, gemfibrozil and

287 indomethacin were very similar to previous studies (Busetti et al. 2009). Concentrations

288 of pharmaceuticals remained fairly constant in the first steps of the AWRP because UF

289 cannot efficiently remove organic micropollutants. RO reduced all chemicals to below

290 detection except triclosan, which was detected for the first time at its LOD of $0.01 \mu \mathrm{g} / \mathrm{L}$.

291 In a previous study, clofibric acid, diazepam and naproxen had been occasionally

292 detected but in less than 25\% of the samples (Linge et al. 2012). 
294 monitoring had shown that the estrogens ethinyl estradiol, $17 \beta$-estradiol and estrone were

295 always below detection (Van Buynder et al. 2009). In the present study, estrone levels of

$2965 \mathrm{ng} / \mathrm{L}$ in the WWTP effluent fell below detection limit thereafter. The surfactant 4-t-

297 octylphenol was only detected in the WWTP influent. The plasticizer bisphenol A was

298 also detected in the blanks. The concentrations of bisphenol A listed in the ESM, Table

299 S3 represent the measured values minus the blank value and are therefore of high

300 uncertainty but positive detections are consistent with previous work (Van Buynder et al. $3012009)$.

302 Antibiotics were grouped separately from the pharmaceuticals because they are

303 relevant for the formation of resistant bacterial strains. Secondary treatment greatly

304 reduced the concentration of antibiotics with only erythromycin and sulfamethoxazole

305 detected in the WWTP effluent. Concentrations remained stable during the first steps of

306 the AWRP but RO efficiently rejected all antibiotics, which is again consistent with

307 previous work (Linge et al. 2012, Busetti et al. 2013).

308 XRCs are good indicator compounds as they are frequently detected in fairly

309 constant concentrations up to UF but are well removed by RO (Busetti et al. 2010), which

310 was confirmed in the present study (Figure 2).

311 Pesticides were generally well removed during treatment with only MCPA and

312 3,4-dichloraniline detected at very low levels. MCPA was detected at 50 times higher

313 concentration in the WWTP effluent than in previous work, therefore it is not astonishing

314 that it was detected post RO in the present study, and not previously (Rodriguez et al. 
315 2012, Busetti et al. 2013). Concentrations in WWTP effluent were similar to previous

316 work for atrazine, 2,4-dichlorophenoxyacetic acid and simazine (Rodriguez et al. 2012).

317 The group of compounds called "others" was comprised of benzothiazoles,

318 fragrance chemicals and flame retardants. 5-Methyl-1H-benzotriazole (tolytriazole) was

319 the only chemical in this group detected at $\mathrm{ng} / \mathrm{L}$ levels post $\mathrm{RO}$, which is consistent with

320 previous findings (Busetti et al. 2013, Loi et al. 2013). The fragrance chemicals were

321 analyzed for the first time at this plant and while their concentrations were constant

322 during the WWTP and the initial AWRP steps, RO removed them below detection

323 (Figure 2). Previously, galaxolidon a biological transformation by-products of the musk

324 fragrance galaxolide, was detected in post RO and post UV samples at average

325 concentrations of 31 and $19 \mathrm{ng} / \mathrm{L}$, respectively.

$326 \quad$ From comparison of the chemical analysis with previous works as discussed

327 above one can conclude that the grab samples taken for the present study are fairly

328 representative and are suitable for bioanalytical assessment and mixture effect studies.

$330 \quad 3.2$ Bioanalytical assessment

331 The highest effect levels in all bioassays were observed in the WWTP influent and RO

332 reject samples, the effects decreased along treatment train (Table 2). Apart from

333 Microtox, effects were below detection limits post RO and post UV disinfection.

334 For the non-specific toxicity, the baseline-TEQ decreased from $26 \mathrm{mg} / \mathrm{L}$ in WWTP

335 influent to $9 \mathrm{mg} / \mathrm{L}$ after secondary treatment (WWTP effluent). The levels remained low

336 at $5-6 \mathrm{mg} / \mathrm{L}$ after ultrafiltration (post UF) and in the mixing tank between UF and RO. 
337 The baseline-TEQ was further reduced to less than $1 \mathrm{mg} / \mathrm{L}$ post $\mathrm{RO}$ and post $\mathrm{UV}$ to levels

338 as low as the blanks (Table 2). These levels were similar to what was observed previously

339 in this plant (Leusch et al. 2014a) (ESM, Figure S2A) and in another Australian AWRP

340 (Macova et al. 2011, Escher et al. 2014a, Tang and Escher 2014), which uses the same

341 treatment processes (ESM, Figure S3A).

342 A consistent trend was observed in the PSII inhibition endpoint, the highest diuron

343 equivalent concentration (DEQ) was observed in RO reject $(0.09 \mu \mathrm{g} / \mathrm{L})$ and the DEQ

344 decreased along the treatment train from $0.07 \mu \mathrm{g} / \mathrm{L}$ in WWTP influent to $0.03 \mu \mathrm{g} / \mathrm{L}$ in

345 WWTP effluent and $0.02 \mu \mathrm{g} / \mathrm{L}$ post UF and mixing tank (Table 2). The DEQs in post RO

346 and post UV were below the detection limit of $0.004 \mu \mathrm{g} / \mathrm{L}$. The EC were very similar to

347 previous work (Leusch et al. 2014a) (ESM, Figure S2B), although in the previous study

$348 \mathrm{EC}_{20}$ not $\mathrm{EC}_{50}$ were measured and the $\mathrm{DEQ}$ levels were much lower than in another

349 AWRP (Tang and Escher 2014) but the removal efficiency by reverse osmosis was again

350 similar (ESM, Figure S3B).

351 The $u m u C$ genotoxicity assay only gave responses when metabolism was not

352 activated with metabolic enzymes. The only sample that was active after metabolic

353 activation by rat liver S9 was the WWTP influent with a 2AAEQ of $2 \mu \mathrm{g} / \mathrm{L}$. The results

354 for 2AAEQs were therefore omitted from Table 2 as they were mainly non-detects.

355 Without metabolic activation, the highest response in the $u m u C$ assay was found in

356 WWTP influent and reject with a 4NQOEQ of $0.6 \mu \mathrm{g} / \mathrm{L}$ (Table 2). The 4NQOEQ levels

357 decreased along the treatment train and were below the detection limit of $0.1 \mu \mathrm{g} / \mathrm{L}$ in post

$358 \mathrm{RO}$ and post $\mathrm{UV}$ samples. A comparison of the $\mathrm{EC}_{\mathrm{IR} 1.5}$ with previous work on the same 
359 AWRP (Leusch et al. 2014a) showed again consistent results (ESM, Figure S2C),

360 although the secondary effluent still showed an effect after metabolic activation in the

361 previous work while it was below detection limit in the present study.

362 For the oxidative stress response, the highest tBHQ equivalent concentration

363 (tBHQEQ) was observed in the RO reject sample at $73 \mu \mathrm{g} / \mathrm{L}$ (Table 2). The tBHQEQ

364 levels decreased along the treatment train from WWTP influent $(32 \mu \mathrm{g} / \mathrm{L})$ to post RO and

365 post UV samples $(<9 \mu \mathrm{g} / \mathrm{L})$. Again a comparison with the other AWRP (Escher et al.

366 2013) revealed a consistent pattern of reduction, although the levels in the WWTP

367 effluent were five times lower in the present study and the levels in the post-UV sample

368 were slightly higher but in the same range as the blanks (ESM, Figure S3C).

$370 \quad 3.4$ Contribution of known chemicals to the observed biological effects

371 The iceberg mixtures explained less than $3 \%$ of the observed cytotoxicity (Figure $3 \mathrm{~A}$ and

372 Table 3). A smaller fraction of effect could be explained for WWTP influent as compared

373 to the samples along the AWRP treatment train (Figure 3A) and the fraction explained

374 was not related to the number of chemicals detected (ESM, Figure S1). The fraction

375 explained in WWTP effluent was similar to previous work (Tang et al. 2013), but larger

376 fractions than in previous work were explained in the other samples (Figure 3A).

377 In contrast, the photosynthesis inhibition was higher in the iceberg mixtures than

378 in the samples (Figure 3B and Table 3), which indicates that PSII-herbicides dominate

379 the mixture effects toward algae, which had previously been confirmed for similar types

380 of samples (Tang and Escher 2014). The lower effects in the samples as compared to the 
381 iceberg mixtures can be rationalized by the fact that the chemical analysis was corrected

382 for SPE recovery while for the bioassays the composition of the samples is unknown and

383 one cannot correct for SPE recovery. While SPE recovery of pesticides is typically close

384 to $100 \%$ (Escher et al. 2014b), any recovery lower than $100 \%$ will cause the effect of the

385 icebergs appear to be higher than of the extracted samples.

386 The detected chemicals explained only $0.04 \%$ to $0.7 \%$ of the observed oxidative

387 stress response (Figure 3C and Table 3), which was in the same order of magnitude as

388 previous work (Escher et al. 2013). Interestingly the WWTP influent was an outlier with

389 an unusual high fraction explained ( $0.7 \%)$, while for the cytotoxicity assay there was a

390 remarkably low fraction explained $(0.2 \%)$. This observation is presumably an artifact as

391 the WWTP influent also had a high organic matter content and the detection limits of

392 individual chemicals were higher, so that in some cases chemicals were below the LOD

393 even though they were present in the WWTP effluent (ESM, Figure S1 and Table S3).

394 Overall, the fraction of BEQ explained by known chemicals was generally higher

395 in this study that in the previous study (empty diamonds in Figure 3). This can be

396 explained by the fact that a higher number of chemicals were quantified in the present

397 study than in the previous studies (Escher et al. 2013, Tang et al. 2013) and is likely not

398 related to a different composition of the water samples.

399

4003.5 Contribution of individual chemical groups to the overall iceberg mixtures 
401 All individual chemical groups were tested in all bioassays. Positive responses were

402 found only in the assays for cytotoxicity, photosynthesis inhibition and oxidative stress

403 response and there was no response in the genotoxicity assay (Table 2).

404 Figure 4 shows the cumulative BEQs of the six chemical groups in comparison

405 with the experimental BEQ of the entire iceberg mixture. With one exception, the

406 individual group BEQs summed up to the experimental BEQ of the entire iceberg

407 mixture, which confirms the suitability of the experimental design and concentration

408 addition of individual groups.

409 For the cytotoxicity endpoint, pesticides and pharmaceuticals had an equal share

410 to the BEQ in the WWTP influent sample, while pesticides dominated in all other

411 samples (Table 2, Figure 4A). This is consistent with the general notion that many

412 pesticides are more recalcitrant towards secondary treatment than many pharmaceuticals.

413 Of the other four chemical groups only the EDCs had a minor contribution of $3 \%$ in the

414 WWTP influent and $12 \%$ in the RO reject (Table 2). Post RO the BEQ levels were very

415 low with pharmaceuticals and others dominating the BEQ.

416 As expected, the group of pesticides dominated the overall DEQ quantified in the 417 photosynthesis inhibition assay. Antibiotics contributed only $1 \%$ to the DEQ in the

418 WWTP influent but were below detection limit thereafter. Pharmaceuticals contributed

419 between $0.3 \%$ and $1.8 \%$ to the DEQ. Post RO, no photosynthesis inhibition was detected.

420 In the RO reject the pharmaceuticals had a nominal contribution, which must be an

421 artifact of the mixture calculations, which are extrapolations, as the iceberg mixture itself 422 was not active. 
424 the BEQ of the iceberg mixtures and the sum of the BEQ of the individual groups (Figure

425 4C), with the exception of the WWTP influent sample where the pharmaceuticals were

426 below detection limit, which is probably an extrapolation artifact and not real. In the

427 remaining samples, the pesticides caused approximately $60 \%$ of tBHQEQ, the

428 pharmaceuticals $30 \%$ and the others $10 \%$, and these proportions did not vary much

429 during treatment despite the overall tBHQEQ varying by more than ten-fold, indicating

430 that there was no preferential removal for any group.

431

\section{4. Conclusions}

433 A previous study had compared, qualitatively, chemical analysis with in-vitro and in-vivo

434 bioassays and found that treatment of wastewater in the investigated plant reduced

435 chemicals as well as effects below the detection limit (Leusch et al. 2014a). The present

436 study confirmed previous findings of Leusch et al. (2014a) and went a step further: for

437 the first time chemical monitoring was linked with effect-based assessment in a

438 quantitative manner and related to the individual groups of chemicals.

439 Mixture toxicity modeling applying the mixture model of concentration addition,

440 which is valid for chemicals acting according to the same mode of action, confirmed

441 previous findings that chemicals typically present in wastewater act concentration-

442 additive in the applied bioassays (Escher et al. 2013, Tang et al. 2013, Tang and Escher

443 2014). After this was confirmed, it was possible to quantify (a) which fraction of effect 
444 could be explained by the detected chemicals and (b) which groups of chemicals

445 influenced or even dominated the mixture effects.

446 Although a total of 299 chemicals were screened and a higher fraction of

447 biological effect could be explained than in previous studies (Escher et al. 2013, Tang et

448 al. 2013), the detected chemicals explained less than $3 \%$ of cytotoxicity and less than $1 \%$

449 of oxidative stress response. As in earlier work (Tang and Escher 2014), all responsible

450 chemicals for photosynthesis inhibition were included in the analytical target list. This

451 finding can be rationalized by the fact that pesticides explained the majority of this effect,

452 which does not come unexpected because the pesticide group contained several highly

453 potent photosynthesis inhibitors such as diuron, hexazinone and simazine (ESM, Table

454 S3). What was even more interesting is the novel finding that pesticides were also

455 responsible for around two third of the effects of the iceberg mixtures in the cytotoxicity

456 and oxidative stress response assays. Thus it appears that in addition to a focus on

457 endocrine disruptors (Leusch et al. 2014a), pesticide monitoring is of high relevance

458 despite the source water is of domestic origin and Australia has a separate sewerage

459 systems. This observation has implications for risk assessment and management. Given

460 that even the most thorough chemical analysis could account for only a small fraction of

461 the non-specific toxicity and adaptive stress response, we propose to always complement

462 chemical monitoring with cell-based bioassays, which constitute efficient and high-

463 throughput monitoring tools.

464

465 Acknowledgements 
466 This research was funded by the Australian Water Recycling Centre of Excellence (set up

467 under the Commonwealth Government's Water for the Future Program), Water

468 Corporation of Western Australia, and the Australian Research Council (FT100100694).

469 The National Research Centre for Environmental Toxicology (Entox) is a joint venture of

470 The University of Queensland and Queensland Health Forensic and Scientific Services

471 (QHFSS). We thank Mriga Dutt, Eva Glenn and Shane McCarty for experimental

472 assistance. We thank Frederic Leusch for providing the raw data of his previous bioassay

473 work at this plant. We thank Palenque Blair, Scott Garbin, Stacey Hamilton, and Bradley

474 Edwards from Water Corporation and the Project Advisory Committee (Judy Blackbeard, 475 Stuart Khan, Andrew Humpage) for helpful discussions and/or review of the manuscript.

477 Appendix A. Supplementary Data

478 Supplementary data related to this article can be found at

479 http://dx.doi.org/10.1016/j.watres......

480

481 References

482 Binnie, C. and Kimber, M. (2009) Basic Water Treatment, 4th Edition, Thomas Tellford $483 \quad$ Limited.

484 Busetti, F., Linge, K.L. and Heitz, A. (2009) Analysis of pharmaceuticals in indirect 485 potable reuse systems using solid-phase extraction and liquid chromatography486 tandem mass spectrometry. Journal of Chromatography A 1216(31), 5807-5818. 
Busetti, F., Linge, K.L., Rodriguez, C. and Heitz, A. (2010) Occurrence of iodinated Xray contrast media in indirect potable reuse systems. Journal of Environmental Science and Health Part a-Toxic/Hazardous Substances \& Environmental

Busetti, F., Ruff, M., Linge, K.L., Charrois, J. and Edwards., B. (2013) The Hunt for Known and Unknown Chemicals Contributing to Dissolved Organic Carbon in Reverse Osmosis and UV Treated Wastewater. Micropol and Ecohazard 2013, 8th IWA Specialist Conference on Assessment and Control of Micropollutants/Hazardous Substances in Water.Zurich, Switzerland, 16-20 June 2013.

Drewes, J.E., Sedlak, D., Snyder, S. and Dickenson, E. (2008) Development of indicators and surrogates for chemical contaminant removal during wastewater treatment and reclamation., Water Reuse Foundation, Alexandria, VA, USA.

Escher, B. and Leusch, F. (2012) Bioanalytical tools in water quality assessment, IWA Publishing, London, UK.

Escher, B.I., Allinson, M., Altenburger, R., Bain, P., Balaguer, P., Busch, W., Crago, J., Humpage, A., Denslow, N.D., Dopp, E., Hilscherova, K., Kumar, A., Grimaldi, M., Jayasinghe, B.S., Jarosova, B., Jia, A., Makarov, S., Maruya, K.A., Medvedev, A., Mehinto, A.C., Mendez, J.E., Poulsen, A., Prochazka, E., Richard, J., Schifferli, A., Schlenk, D., Scholz, S., Shiraishi, F., Snyder, S., Su, G., Tang, J., Burg, B.v.d., Linden, S.v.d., Werner, I., Westerheide, S.D., Wong, C.K.C., Yang, M., Yeung, B., Zhang, X. and Leusch, F.D.L. (2014a) Benchmarking organic micropollutants in 
wastewater, recycled water and drinking water with in vitro bioassays.

$510 \quad$ Environmental Science \& Technology 48, 1940-1956.

511 Escher, B.I., Bramaz, N., Mueller, J.F., Quayle, P., Rutishauser, S. and Vermeirssen,

512 E.L.M. (2008) Toxic equivalent concentrations (TEQs) for baseline toxicity and

513 specific modes of action as a tool to improve interpretation of ecotoxicity testing of

514 environmental samples. Journal of Environmental Monitoring 10(5), 612-621.

515 Escher, B.I., Dutt, M., Maylin, E., Tang, J.Y.M., Toze, S., Wolf, C.R. and Lang, M.

516 (2012) Water quality assessment using the AREc32 reporter gene assay indicative

517 of the oxidative stress response pathway. Journal of Environmental Monitoring 14, $518 \quad 2877-2885$

519 Escher, B.I., Tang, J.Y.M., Poulsen, A., Leusch, F., Snyder, S. and Jia, A. (2014b)

520 Development of bio-analytical techniques to assess the potential human health

521 impacts of recycled water, WateReuse Research Foundation, WateReuse Research

$522 \quad$ Foundation, Alexandria, VA, USA.

523 Escher, B.I., van Daele, C., Dutt, M., Tang, J.Y.M. and Altenburger, R. (2013) Most

524 oxidative stress response in water samples comes from unknown chemicals: the

525 need for effect-based water quality trigger values. Environmental Science \&

$526 \quad$ Technology 47(13), 7002-7011.

527 Gupta, V. and Ali, I. (2013) Environmental Water. Advances in Treatment, Remediation 528 and Recycling. Gupta, V. and Ali, I. (eds), Elsevier. 
529 Hawker, D.W., Cumming, J.L., Neale, P.A., Bartkow, M.E. and Escher, B.I. (2011) A

530 screening level fate model of organic contaminants from advanced water treatment

531 in a potable water supply reservoir. Water Research 45(2), 768-780.

532 ISO11348-3 (1998) Water quality - determination of the inhibitory effect of water

533 samples on the light emission of Vibrio Fischeri (luminescent bacteria test),

534 International Organization for Standardization (ISO), Geneva, Switzerland.

535 ISO13828 (1999) Water quality - Determination of the genotoxicity of water and waste

536 water using the umu-test, International Organization for Standardization (ISO),

$537 \quad$ Geneva, Switzerland.

538 Khan, S. and Roser, D. (2007) Risk assessment and health effects of indirect potable

539 reuse schemes, Report No.: 207/01; Centre for Water and Waste Technology,

540 School of Civil and Environmental Engineering, University of New South Wales:

$541 \quad$ New South Wales, Australia.

542 Leusch, F.D.L., Khan, S.J., Gagnon, M.M., Quayle, P., Trinh, T., Coleman, H., Rawson,

543 C., Chapman, H., Blair, P., Nice, H. and Reitsema, T. (2014a) Assessment of

544 wastewater and recycled water quality: A comparison of lines of evidence from in

545 vitro, in vivo and chemical analyses. Water Research 50, 420-431.

546 Leusch, F.D.L., Khan, S.J., Laingam, S., Prochazka, E., Trinh, T., Froscio, S., Chapman,

547 H. and Humpage, A. (2014b) Assessment of the application of bioanalytical tools

548 as surrogate measure of chemical contaminants in recycled water. Water Research

$549 \quad 49,300-315$. 
550 Linge, K.L., Blair, P., Busetti, F., Rodriguez, C. and Heitz, A. (2012) Chemicals in

551 reverse osmosis-treated wastewater: occurrence, health risk, and contribution to

552 residual dissolved organic carbon. Journal of Water Supply Research and

553 Technology-Aqua 61(8), 494-505.

554 Loi, C.H., Busetti, F., Linge, K.L. and Joll, C.A. (2013) Development of a solid-phase

555 extraction liquid chromatography tandem mass spectrometry method for

556 benzotriazoles and benzothiazoles in wastewater and recycled water. Journal of

557 Chromatography A 1299, 48-57.

558 Macova, M., Toze, S., Hodgers, L., Mueller, J.F., Bartkow, M.E. and Escher, B.I. (2011)

559 Bioanalytical tools for the evaluation of organic micropollutants during sewage

560 treatment, water recycling and drinking water generation. Water Research 45(14),

$561 \quad 4238-4247$.

562 Muller, R., Schreiber, U., Escher, B.I., Quayle, P., Nash, S.M.B. and Mueller, J.F. (2008)

563 Rapid exposure assessment of PSII herbicides in surface water using a novel

564 chlorophyll a fluorescence imaging assay. Science of The Total Environment

$565 \quad 401(1-3), 51-59$.

566 Nagy, S.R., Sanborn, J.R., Hammock, B.D. and Denison, M.S. (2002) Development of a

567 green fluorescent protein-based cell bioassay for the rapid and inexpensive

568 detection and characterization of Ah receptor agonists. Toxicological Sciences

$569 \quad 65(2), 200-210$. 
570 National Research Council (1998) Issues in potable reuse: The viability of augmenting

571 drinking water supplies with reclaimed water, National Academic Press,

572 Washington, DC, USA.

573 NHMRC (2011) Australian Drinking Water Guidelines Paper 6 National Water Quality

574 Management Strategy., National Health and Medical Research Council (NHMRC)

575 and the Natural Resource Management Ministerial Council, Canberra, Australia. .

576 NRMMC \& EPHC \& NHMRC (2008) Australian guidelines for water recycling:

577 managing health and environmental risks (phase 2). Augmentation of drinking

578 water supplies, National Water Quality Management Strategy (NWQMS), Natural

579 Resource Management Ministerial Council (NRMMC), Environment Protection

580 and Heritage Council (EPHC) and National Health and Medical Research Council

581 (NHRMC), Canberra, Australia. http://www.ephc.gov.au/taxonomy/term/39.

582 Rodriguez, C., Taylor, P., Devine, B., Van Buynder, P., Weinstein, P. and Cook, A.

583 (2012) Assessing Health Risks from Pesticides in Recycled Water: A Case Study of

584 Augmentation of Drinking Water Supplies in Perth, Western Australia. Human and

$585 \quad$ Ecological Risk Assessment 18(6), 1216-1236.

586 Rodriguez, C., Van Buynder, P., Lugg, R., Blair, P., Devine, B., Cook, A. and Weinstein,

587 P. (2009) Indirect Potable Reuse: A Sustainable Water Supply Alternative.

$588 \quad$ International Journal of Environmental Research and Public Health 6(3), 1174-

$589 \quad 1209$.

590 Rogers, J.M. and Denison, M.S. (2000) Recombinant cell bioassays for endocrine

591 disruptors: Development of a stably transfected human ovarian cell line for the 

Toxicology - a Journal of Basic and Applied Research 13(1), 67-82.

594 Rutishauser, B.V., Pesonen, M., Escher, B.I., Ackermann, G.E., Aerni, H.R., Suter, 595 M.J.F. and Eggen, R.I.L. (2004) Comparative analysis of estrogenic activity in sewage treatment plant effluents involving three in vitro assays and chemical analysis of steroids. Environmental Toxicology and Chemistry 23(4), 857-864.

598 Sedlak, D. (2014) Water 4.0. The Past, Present, and Future of the World's Most Vital $599 \quad$ Resource, Yale University Press.

600 Snyder, S., Wert, E., Lei, H., Westerhoff, P. and Yoon, Y. (2007) Removal of EDCs and 601 pharmaceuticals in drinking and water reuse processes, AwwaRF \& AWWA, 602 Denver, CO.

603 Tang, J.Y.M. and Escher, B.I. (2014) Realistic environmental mixtures of micropollutants 604 in wastewater, recycled water and surface water: herbicides dominate the mixture 605 toxicity towards algae. Environmental Toxicology and Chemistry, in press, 10.1002/etc. 2579 .

607 Tang, J.Y.M., McCarty, S., Glenn, E., Neale, P.A., Warne, M.S. and Escher, B.I. (2013)

608 Mixture effects of organic micropollutants present in water: towards the 609 development of effect-based water quality trigger values for baseline toxicity.

$610 \quad$ Water Research 47(10), 3300-3314.

611 Van Buynder, P., Lugg, R., Rodriguez, C., Bromley, M., Filmer, J., Blair, P., Handyside, 612 M., Higginson, S., Turner, N., Lord, O., Taylor, P., Courtney, K., Newby, C., Heitz, 613 A., Linge, K., Blythe, J., Busetti, F. and Toze, S. (2009) Premier's Collaborative 
614 Research Program (2005-2008): Characterising Treated Wastewater For Drinking

615 Purposes Following Reverse Osmosis Treatment. Technical Report. Department of

$616 \quad$ Health, Western Australia.ISBN 174043560 5. 376 pages.

617 van der Bruggen, B. (2010) Sustainable Water for the Future: Water Recycling versus

618 Desalination. Escobar, I. and Schäfer, A.I. (eds), Elsevier.

619 Wang, X.J., Hayes, J.D. and Wolf, C.R. (2006) Generation of a stable antioxidant

620 response element-driven reporter gene cell line and its use to show redox-dependent

621 activation of Nrf2 by cancer chemotherapeutic agents. Cancer Research 66(22),

$622 \quad 10983-10994$.

623 Water Corporation (2013) Groundwater Replenishment Trial. Final Report.

624 http://www.watercorporation.com.au/water-supply-and-services/solutions-to-

625 perths-water-supply/groundwater-replenishment.

626

627

628 


\section{Figure Captions}

630 Figure 1. Overview of the treatment processes at the Wastewater Treatment Plant

631 (WWTP) and Advanced Water Recycling Plant (AWRP). The blue boxes denote the

632 points where the samples were collected (text in italics).

634 Figure 2. Concentration of 65 chemicals detected in at least one water sample and used

635 for the iceberg mixture experiments (Table S3) (from 299 analyzed chemicals and a total

636 of 95 detected chemicals); (n) refers to the number of samples with concentrations above

637 the limit of detection. The detected chemicals were clustered in six groups:

638 pharmaceuticals, endocrine disrupting compounds (EDCs), pesticides, antibiotics, x-ray

639 contrast media (XRC), and others. $\mathrm{N}$ refers to the number of samples that were above the

640 detection limit. The different symbols denote the different water samples (circle: WWTP

641 influent, diamond: WWTP effluent, square: post UV, down-facing triangle: mixing tank,

642 up-facing triangle: RO reject, star: post RO). The black bars denote the guideline values

643 (GV) of the AGWR (NRMMC \& EPHC \& NHMRC 2008). The only chemical that was

644 included and does not have an AGWR GV is fipronil (but included in ADWG).

645

646 Figure 3. Contribution of detected chemicals for (A) non-specific toxicity as baseline-

647 TEQ (Microtox), (B) DEQ (IPAM) and (C) oxidative stress response as tBHQEQ

648 (AREc32). Filled diamonds represent experimental data from the present study, open

649 diamonds represent reported data from other recycled water plants and surface water

650 (Tang et al. 2013, Escher et al. 2014b). 
652 Figure 4. Cumulative bioanalytical equivalent concentrations of the iceberg mixtures in 653 comparison with the cumulative BEQs of the six chemical groups: (A) non-specific

654 toxicity (Microtox), (B) photosynthesis inhibition (IPAM), (C) oxidative stress response 655 (AREc32).

656

657

658 
660 Table 1. Bioassays used in this study, reference chemicals for the derivation of BEQ and their effect concentrations EC

\begin{tabular}{|c|c|c|c|c|c|c|}
\hline Mode of action & Bioassay & $\begin{array}{l}\text { Literature } \\
\text { reference } \\
\text { (assay } \\
\text { principle) / } \\
\text { (method } \\
\text { applied) }\end{array}$ & $\begin{array}{l}\text { Reference } \\
\text { compound }\end{array}$ & $\begin{array}{l}\text { Effect } \\
\text { concentration } \\
\text { EC }\end{array}$ & $\begin{array}{l}\text { Bioanalytical } \\
\text { equivalent } \\
\text { concentration } \\
\text { BEQ }\end{array}$ & $\begin{array}{l}\text { Limit of } \\
\text { detection }^{a}\end{array}$ \\
\hline $\begin{array}{l}\text { Non-specific: } \\
\text { cytotoxicity }\end{array}$ & $\begin{array}{l}\text { Bioluminescence } \\
\text { inhibition test with } \\
\text { Vibrio fischeri } \\
\text { (Microtox) }\end{array}$ & $\begin{array}{l}\text { (ISO11348-3 } \\
\text { 1998)/ (Tang et } \\
\text { al. 2013) }\end{array}$ & $\begin{array}{l}\text { Virtual baseline } \\
\text { toxicant (a } \\
\text { model chemical } \\
\text { with } \log \mathrm{K}_{\mathrm{ow}}=3 \\
\text { and a molecular } \\
\text { weight of } 300 \mathrm{~g} \\
\mathrm{~mol}^{-1} \text { ) }\end{array}$ & $\begin{array}{l}\mathrm{EC}_{50}=66 \pm \\
6.7 \mathrm{mg} / \mathrm{L}\end{array}$ & $\begin{array}{l}\text { Baseline toxicity } \\
\text { equivalent } \\
\text { concentration } \\
\text { (Baseline-TEQ) }\end{array}$ & $0.13 \mathrm{mg} / \mathrm{L}$ \\
\hline $\begin{array}{l}\text { Specific: } \\
\text { photosynthesis } \\
\text { inhibition }\end{array}$ & $\begin{array}{l}\text { Combined algae } \\
\text { test with } \\
\text { Pseudokirchneriella } \\
\text { subcapitata }\end{array}$ & $\begin{array}{l}\text { (Muller et al. } \\
\text { 2008)/ (Escher } \\
\text { et al. 2008) }\end{array}$ & Diuron & $\begin{array}{l}\mathrm{EC}_{50}=1.81 \pm \\
0.45 \mu \mathrm{g} / \mathrm{L}\end{array}$ & $\begin{array}{l}\text { Diuron } \\
\text { equivalent } \\
\text { concentration } \\
\text { (DEQ) }\end{array}$ & $0.004 \mu \mathrm{g} / \mathrm{L}$ \\
\hline $\begin{array}{l}\text { Reactive: } \\
\text { genotoxicity }\end{array}$ & umuC assay $-\mathrm{S} 9$ & $\begin{array}{l}\text { (ISO13828 } \\
\text { 1999)/ (Macova } \\
\text { et al. 2011) }\end{array}$ & $\begin{array}{l}\text { 4- } \\
\text { Nitroquinoline- } \\
\text { N-oxide } \\
\text { (4NQO) } \\
\end{array}$ & $\begin{array}{l}\mathrm{EC}_{\mathrm{IR} 1.5}=9.1 \pm \\
3.8 \mu \mathrm{g} / \mathrm{L}\end{array}$ & $\begin{array}{l}4 \mathrm{NQO} \\
\text { equivalent } \\
\text { concentration } \\
\text { (4NQOEQ) } \\
\end{array}$ & $0.10 \mu \mathrm{g} / \mathrm{L}$ \\
\hline $\begin{array}{l}\text { Reactive: } \\
\text { genotoxicity } \\
\text { after metabolic } \\
\text { activation }\end{array}$ & umuC assay $+\mathrm{S} 9$ & $\begin{array}{l}\text { (ISO13828 } \\
\text { 1999)/ (Macova } \\
\text { et al. 2011) }\end{array}$ & $\begin{array}{l}2- \\
\text { Aminoathracene } \\
(2 \mathrm{AA})\end{array}$ & $\begin{array}{l}\mathrm{EC}_{\mathrm{IR} 1.5}=46.7 \\
\pm 27.6 \mu \mathrm{g} / \mathrm{L}\end{array}$ & $\begin{array}{l}\text { 2AA equivalent } \\
\text { concentration } \\
\text { (2AAEQ) }\end{array}$ & $0.05 \mu \mathrm{g} / \mathrm{L}$ \\
\hline
\end{tabular}




\begin{tabular}{|c|c|c|c|c|c|}
\hline $\begin{array}{l}\text { Reactive: } \\
\text { oxidative } \\
\text { stress }\end{array}$ & AREc32 assay & $\begin{array}{l}\text { (Wang et al. } \\
\text { 2006)/ (Escher } \\
\text { et al. 2012) }\end{array}$ & $\begin{array}{l}\text { t-butyl- } \\
\text { hydroquinone } \\
\text { (tBHQ) }\end{array}$ & $\begin{array}{l}\mathrm{EC}_{\mathrm{IR} 1.5}=0.15 \\
\pm 0.03 \mathrm{mg} / \mathrm{L}\end{array}$ & $\begin{array}{l}\text { tBHQ equivalent } 8.64 \mu \mathrm{g} / \mathrm{L} \\
\text { concentration } \\
\text { (tBHQEQ) }\end{array}$ \\
\hline
\end{tabular}

661

${ }^{a}$ Limit of detection calculation from the equivalent concentration caused by a effect of 3 times the standard deviation of the controls. 


\begin{tabular}{|c|c|c|c|c|c|c|c|c|c|}
\hline $\begin{array}{l}\text { Sampling site / } \\
\text { treatment }\end{array}$ & $\begin{array}{l}\text { WWTP } \\
\text { Influent }\end{array}$ & $\begin{array}{l}\text { WWTP } \\
\text { Effluent }\end{array}$ & $\begin{array}{l}\text { Post } \\
\text { UF }\end{array}$ & $\begin{array}{l}\text { Mixing } \\
\text { Tank }\end{array}$ & Post RO & $\begin{array}{l}\text { Post } \\
\text { UV }\end{array}$ & $\begin{array}{l}\text { RO } \\
\text { Reject }\end{array}$ & $\begin{array}{l}\text { Lab } \\
\text { Blank }\end{array}$ & $\begin{array}{l}\text { Trip } \\
\text { Blank }\end{array}$ \\
\hline \multicolumn{10}{|c|}{ V. fischeri bioluminescence inhibition assay } \\
\hline $\begin{array}{l}\text { Baseline-TEQ } \\
\left(\mathrm{mg} \mathrm{L}^{-1}\right)\end{array}$ & $\begin{array}{l}25.9 \pm \\
0.72 \\
\end{array}$ & $9.15 \pm 0.07$ & $5.12 \pm 0.78$ & $\begin{array}{l}5.83 \pm \\
0.65 \\
\end{array}$ & $\begin{array}{l}0.43 \pm \\
0.09\end{array}$ & $\begin{array}{l}0.74 \pm \\
0.10 \\
\end{array}$ & $\begin{array}{l}29.9 \pm \\
1.0\end{array}$ & $\begin{array}{l}0.40 \pm \\
0.04\end{array}$ & $\begin{array}{l}0.29 \pm \\
0.0\end{array}$ \\
\hline $\begin{array}{l}\text { Baseline-TEQ } \\
\left(\mathrm{mg} \mathrm{L}^{-1}\right)\end{array}$ & $\begin{array}{l}0.04 \pm \\
0.02\end{array}$ & $0.11 \pm 0.03$ & $0.16 \pm 0.03$ & $\begin{array}{l}0.13 \pm \\
0.02\end{array}$ & $\begin{array}{l}0.003 \pm \\
0.004\end{array}$ & n.t. & $\begin{array}{l}0.37 \pm \\
0.07\end{array}$ & n.t. & n.t. \\
\hline $\begin{array}{l}\text { Baseline-TEQEDC }(\mu \mathrm{g} \\
\left.\mathrm{L}^{-1}\right)\end{array}$ & $\begin{array}{l}1.81 \pm \\
1.67 \\
\end{array}$ & $0.30 \pm 0.07$ & $0.44 \pm 0.10$ & $\begin{array}{l}0.04 \pm \\
0.01\end{array}$ & $\begin{array}{l}0.30 \pm \\
0.09\end{array}$ & n.t. & $\begin{array}{l}2.22 \pm \\
0.49 \\
\end{array}$ & n.t. & n.t. \\
\hline $\begin{array}{l}\text { Baseline-TEQXRC }(\mu \mathrm{g} \\
\left.\mathrm{L}^{-1}\right)\end{array}$ & $<0.07$ & $<0.05$ & $<0.05$ & $<0.05$ & n.t. & n.t. & $<0.2$ & n.t. & n.t. \\
\hline $\begin{array}{l}\text { Baseline-TEQ antibiotics } \\
\left(\mu \mathrm{g} \mathrm{L}^{-1}\right)\end{array}$ & $\begin{array}{l}0.15 \pm \\
0.04\end{array}$ & $0.09 \pm 0.03$ & $0.10 \pm 0.05$ & $\begin{array}{l}0.06 \pm \\
0.04\end{array}$ & n.t. & n.t. & $\begin{array}{l}0.16 \pm \\
0.18\end{array}$ & n.t. & n.t. \\
\hline $\begin{array}{l}\text { Baseline-TEQ } Q_{\text {pesticides }} \\
\left(\mu \mathrm{g} \mathrm{L}^{-1}\right)\end{array}$ & $\begin{array}{l}25.4 \pm \\
10.7\end{array}$ & $96.0 \pm 34.1$ & $132 \pm 31.0$ & $\begin{array}{l}69.8 \pm \\
35.8\end{array}$ & $\begin{array}{l}0.14 \pm \\
0.03\end{array}$ & n.t. & $\begin{array}{l}252 \pm \\
109\end{array}$ & n.t. & n.t. \\
\hline $\begin{array}{l}\text { Baseline- } \\
\text { TEQ } \\
\left.\mathrm{L}^{-1}\right)\end{array}$ & $\begin{array}{l}25.6 \pm \\
35.7\end{array}$ & $9.1 \pm 2.7$ & $7.3 \pm 2.7$ & $11.7 \pm 2.7$ & $\begin{array}{l}0.94 \pm \\
0.67\end{array}$ & n.t. & $\begin{array}{l}39.0 \pm \\
13.5\end{array}$ & n.t. & n.t. \\
\hline $\begin{array}{l}\text { Baseline-TEQ others } \\
\left(\mu \mathrm{g} \mathrm{L}^{-1}\right)\end{array}$ & $\begin{array}{l}0.05 \pm \\
0.01 \\
\end{array}$ & $2.8 \pm 0.6$ & $4.0 \pm 1.0$ & $2.8 \pm 0.9$ & $1.1 \pm 0.2$ & n.t. & $\begin{array}{l}15.8 \pm \\
5.6 \\
\end{array}$ & n.t. & n.t. \\
\hline \multicolumn{10}{|c|}{ IPAM photosynthesis inhibition assay } \\
\hline $\operatorname{DEQ}_{\text {water }}\left(\mu \mathrm{g} \mathrm{\textrm {L } ^ { - 1 } )}\right.$ & $\begin{array}{l}0.073 \pm \\
0.023\end{array}$ & $\begin{array}{l}0.033 \pm \\
0.012\end{array}$ & $\begin{array}{l}0.025 \pm \\
0.006\end{array}$ & $\begin{array}{l}0.017 \pm \\
0.004\end{array}$ & $<0.004$ & $\begin{array}{l}< \\
0.004\end{array}$ & $\begin{array}{l}0.11 \pm \\
0.02\end{array}$ & $\begin{array}{l}< \\
0.004\end{array}$ & $\begin{array}{l}< \\
0.004\end{array}$ \\
\hline $\operatorname{DEQ}_{\text {iceberg }}\left(\mu \mathrm{g} \mathrm{L^{-1 }}\right)$ & $\begin{array}{l}0.10 \pm \\
0.04\end{array}$ & $0.11 \pm 0.03$ & $0.10 \pm 0.03$ & $\begin{array}{l}0.10 \pm \\
0.03\end{array}$ & $\begin{array}{l}2.5 \pm 1.2 \\
\times 10^{-5}\end{array}$ & n.t. & $\begin{array}{l} \\
5.5 \times 10 \\
-4\end{array}$ & n.t. & \\
\hline
\end{tabular}




\begin{tabular}{|c|c|c|c|c|c|c|c|c|c|}
\hline$\overline{\left.\text { DEQEDC }_{\text {EDg L }} \mathbf{n}^{-1}\right)}$ & $2.9 \times 10^{-2}$ & $\begin{array}{l}8.8 \pm 3.3 \\
\times 10^{-4}\end{array}$ & $\begin{array}{l}1.2 \times 10^{-3} \pm \\
3.0 \times 10^{-4}\end{array}$ & $\begin{array}{l}1.0 \pm \\
0.3 \times 10^{-4}\end{array}$ & $\begin{array}{l}7.7 \pm \\
5.0 \times 10^{-4}\end{array}$ & n.t. & n.t. & n.t. & n.t. \\
\hline$\overline{D E Q X R C}\left(n g L^{-1}\right)$ & $<3.4 \times 10^{-3}$ & $<2.4 \times 10^{-3}$ & $<2.5 \times 10^{-3}$ & $<2.3 \times 10^{-3}$ & n.t. & n.t. & $\begin{array}{l}< \\
9.4 \times 10\end{array}$ & n.t. & n.t. \\
\hline $\operatorname{DEQ}_{\text {antibiotics }}\left(\mathrm{ng} \mathrm{L}^{-1}\right)$ & $\begin{array}{l}0.35 \pm \\
0.15\end{array}$ & $<2.6 \times 10^{-3}$ & $<2.4 \times 10^{-3}$ & $<2.4 \times 10^{-3}$ & n.t. & n.t. & $\begin{array}{l}<.4 \times 10 \\
-3\end{array}$ & n.t. & n.t. \\
\hline $\operatorname{DEQ}_{\text {pesticides }}\left(\mathrm{ng} \mathrm{L}^{-1}\right)$ & $30 \pm 16$ & $93 \pm 24$ & $60 \pm 30$ & $61 \pm 35$ & $<1.2 \times 10^{-}$ & n.t. & $<0.42$ & n.t. & n.t. \\
\hline $\begin{array}{l}\text { DEQ } \\
\left.\mathrm{L}^{-1}\right)\end{array}$ & $\begin{array}{l}0.55 \pm \\
0.36\end{array}$ & $0.25 \pm 0.14$ & $0.19 \pm 0.15$ & $\begin{array}{l}0.37 \pm \\
0.12\end{array}$ & $\begin{array}{l}<7.8 \times 10^{-} \\
5\end{array}$ & n.t. & $\begin{array}{l}1.34 \pm \\
0.72\end{array}$ & n.t. & n.t. \\
\hline $\operatorname{DEQ}_{\text {others }}\left(\mathrm{ng} \mathrm{L}^{-1}\right)$ & $<5.2 \times 10^{-4}$ & $<6.0 \times 10^{-3}$ & $<6.6 \times 10^{-3}$ & $<6.2 \times 10^{-3}$ & $\begin{array}{l}<8.2 \times 10^{-} \\
4\end{array}$ & n.t. & $\begin{array}{l}< \\
2.6 \times 10\end{array}$ & n.t. & n.t. \\
\hline \multicolumn{10}{|c|}{ umuC genotoxicity assay without metabolic activation } \\
\hline $\begin{array}{l}\text { 4NQOEQ } \\
\text { 1) }\end{array}$ & $\begin{array}{l}0.56 \pm \\
0.17\end{array}$ & $0.24 \pm 0.10$ & $0.09 \pm 0.02$ & $\begin{array}{l}0.13 \pm \\
0.07\end{array}$ & $<0.10$ & $<0.10$ & $\begin{array}{l}0.62 \pm \\
0.18\end{array}$ & $<0.10$ & $<0.10$ \\
\hline $\begin{array}{l}\text { 4NQOEQ } \\
\text { 1) }\end{array}$ & $<4.2 \times 10^{-3}$ & $<6.4 \times 10^{-3}$ & $<7.2 \times 10^{-4}$ & $<6.1 \times 10^{-4}$ & $\begin{array}{l}<3.7 \times 10^{-} \\
6\end{array}$ & n.t. & $\begin{array}{l}< \\
2.1 \times 10\end{array}$ & n.t. & n.t. \\
\hline$\overline{4 N Q O E Q E D C ~}\left(\mu \mathrm{g} \mathrm{L}^{-1}\right)$ & $<3.1 \times 10^{-6}$ & $<3.9 \times 10^{-7}$ & $<4.6 \times 10^{-7}$ & $<4.0 \times 10^{-8}$ & $\begin{array}{l}<2.9 \times 10^{-} \\
7\end{array}$ & n.t. & $\begin{array}{l}<.7 \times 10 \\
-6\end{array}$ & n.t. & n.t. \\
\hline$\overline{4 N Q O E Q X R C}\left(\mu \mathrm{g} \mathrm{L}^{-1}\right)$ & $<3.8 \times 10^{-5}$ & $<1.4 \times 10^{-5}$ & $<1.4 \times 10^{-5}$ & $<1.3 \times 10^{-5}$ & n.t. & n.t. & $\begin{array}{l}< \\
5.3 \times 10\end{array}$ & n.t. & n.t. \\
\hline $\begin{array}{l}\text { 4NQOEQ }{ }_{\text {antibiotics }}(\mu \mathrm{g} \\
\mathrm{L}^{-1} \text { ) }\end{array}$ & $<9.3 \times 10^{-6}$ & $<1.9 \times 10^{-6}$ & $<1.7 \times 10^{-6}$ & $<1.7 \times 10^{-6}$ & n.t. & n.t. & $\begin{array}{l}8.9 \times 10 \\
-6\end{array}$ & n.t. & n.t. \\
\hline
\end{tabular}




\begin{tabular}{|c|c|c|c|c|c|c|c|c|c|}
\hline $\begin{array}{l}\text { 4NQOEQ } \\
\mathrm{L}^{-1} \text { ) }\end{array}$ & $<4.3 \times 10^{-4}$ & $<1.6 \times 10^{-1}$ & $<1.9 \times 10^{-1}$ & $<1.5 \times 10^{-1}$ & $<8.1 \times 10^{-}$ & n.t. & $\begin{array}{l}< \\
4.9 \times 10\end{array}$ & n.t. & n.t. \\
\hline $\begin{array}{l}\text { 4NQOEQ } \\
\left(\mu \mathrm{g} \mathrm{L}^{-1}\right)\end{array}$ & $<3.9 \times 10^{-3}$ & $<5.6 \times 10^{-5}$ & $<5.4 \times 10^{-5}$ & $<5.4 \times 10^{-5}$ & $\begin{array}{l}<5.6 \times 10^{-} \\
8\end{array}$ & n.t. & $\begin{array}{l}< \\
2.5 \times 10\end{array}$ & n.t. & n.t. \\
\hline $\begin{array}{l}\text { 4NQOEQ } \\
\text { 1) }\end{array}$ & $<2.0 \times 10^{-6}$ & $<2.2 \times 10^{-5}$ & $<2.5 \times 10^{-5}$ & $<2.3 \times 10^{-5}$ & ${ }_{6}^{<} 3.1 \times 10^{-}$ & & $\begin{array}{l}< \\
9.6 \times 10\end{array}$ & n.t. & n.t. \\
\hline \multicolumn{10}{|c|}{ AREc32 oxidative stress response assay } \\
\hline tBHQEQ $Q_{\text {water }}\left(\mu \mathrm{g} \mathrm{L}^{-1}\right)$ & $32.4 \pm 0.4$ & $19.5 \pm 7.0$ & $<8.64$ & $<8.64$ & $<8.64$ & $<8.64$ & $\begin{array}{l}73.3 \pm \\
18.8\end{array}$ & $<8.64$ & $<8.64$ \\
\hline $\begin{array}{l}\text { tBHQEQ } \\
\text { 1) }\end{array}$ & $219 \pm 47$ & $5.6 \pm 1.5$ & $5.6 \pm 3.3$ & $6.3 \pm 1.4$ & $\begin{array}{l}0.15 \pm \\
0.07\end{array}$ & n.t. & $\begin{array}{l}25.7 \pm \\
5.02\end{array}$ & n.t. & n.t. \\
\hline tBHQEQEDC $\left(n g L^{-1}\right)$ & $\begin{array}{l}0.01 \pm \\
0.01\end{array}$ & $0.03 \pm 0.01$ & $0.02 \pm 0.01$ & $\begin{array}{l}0.0007 \pm \\
0.0004\end{array}$ & $\begin{array}{l}0.005 \pm \\
0.001\end{array}$ & n.t. & $\begin{array}{l}0.05 \pm \\
0.06\end{array}$ & n.t. & n.t. \\
\hline tBHQEQXRC $\left(\right.$ ng L $\left.^{-1}\right)$ & $<0.08$ & $<0.06$ & $<29$ & $<27$ & n.t. & n.t. & $<110$ & n.t. & n.t. \\
\hline $\begin{array}{l}\text { tBHQEQ } \\
\mathrm{L}^{-1} \text { ) }\end{array}$ & $<0.05$ & $<0.01$ & $<0.01$ & $<0.01$ & n.t. & n.t. & $<0.06$ & n.t. & n.t. \\
\hline $\begin{array}{l}\text { tBHQEQ } \\
\left.\mathrm{L}^{-1}\right)\end{array}$ & $\begin{array}{l}1.75 \pm \\
0.64\end{array}$ & $2.79 \pm 0.75$ & $4.07 \pm 1.65$ & $\begin{array}{l}2.85 \pm \\
0.56 \\
\end{array}$ & $\begin{array}{l}0.003 \pm \\
0.001\end{array}$ & n.t. & $\begin{array}{l}10.0 \pm \\
3.0\end{array}$ & n.t. & n.t. \\
\hline $\begin{array}{l}\text { tBHQEQ } \\
\left(\text { ng L L }^{-1}\right)\end{array}$ & $<51$ & $1.11 \pm 0.76$ & $2.75 \pm 0.56$ & $\begin{array}{l}1.44 \pm \\
0.47\end{array}$ & $\begin{array}{l}0.002 \pm \\
0.001\end{array}$ & n.t. & $\begin{array}{l}14.6 \pm \\
6.3\end{array}$ & n.t. & n.t. \\
\hline $\begin{array}{l}\text { tBHQEQ } \\
\text { 1) }_{\text {others }}\left(\mathrm{ng} \mathrm{L} \mathrm{L}^{-}\right.\end{array}$ & $<0.01$ & $0.43 \pm 0.18$ & $0.48 \pm 0.22$ & $\begin{array}{l}0.46 \pm \\
64.7\end{array}$ & $\begin{array}{l}0.09 \pm \\
0.03\end{array}$ & n.t. & $\begin{array}{l}1.84 \pm \\
0.71\end{array}$ & n.t. & n.t. \\
\hline
\end{tabular}


666 Table 3. Fraction of BEQ explained by detected chemicals (BEQiceberg/BEQ ${ }_{\text {water }}$ ).

\begin{tabular}{|c|c|c|c|c|c|c|}
\hline Sampling site / treatment & $\begin{array}{l}\text { WWTP } \\
\text { Influent }\end{array}$ & $\begin{array}{l}\text { WWTP } \\
\text { Effluent }\end{array}$ & $\begin{array}{l}\text { Post } \\
\text { UF }\end{array}$ & $\begin{array}{l}\text { Mixing } \\
\text { Tank }\end{array}$ & $\begin{array}{l}\text { Post } \\
\text { RO }\end{array}$ & $\begin{array}{l}\text { RO } \\
\text { Reject }\end{array}$ \\
\hline \multicolumn{7}{|c|}{ V. fischeri bioluminescence inhibition assay } \\
\hline Baseline-TEQ $_{\text {iceberg }} /$ Baseline-TEQ $_{\text {water }}$ & $0.2 \%$ & $1.2 \%$ & $3.1 \%$ & $2.2 \%$ & $0.8 \%$ & $1.3 \%$ \\
\hline \multicolumn{7}{|l|}{ IPAM photosynthesis inhibition assay } \\
\hline DEQ $_{\text {iceberg }} /$ DEQ $_{\text {water }}$ & $141 \%$ & $323 \%$ & $405 \%$ & $581 \%$ & - & $0.1 \%$ \\
\hline \multicolumn{7}{|l|}{ AREc32 oxidative stress response assay } \\
\hline tBHQEQ $Q_{\text {iceberg }} /$ tBHQEQ ${ }_{\text {water }}$ & $0.68 \%$ & $0.03 \%$ & $0.07 \%$ & $0.09 \%$ & - & $0.04 \%$ \\
\hline
\end{tabular}

667 